\title{
Capitalism after the Coronavirus: Public Goods, Sustainability and the Role of the State
}

\author{
Maria Rita Pierleoni \\ Department of Economic Planning, Presidency of Council of Ministers, Rome, Italy \\ Email:m.pierleoni3@virgilio.it,mr.pierleoni@governo.it
}

How to cite this paper: Pierleoni, M. R. (2020). Capitalism after the Coronavirus: Public Goods, Sustainability and the Role of the State. Theoretical Economics Letters, 10, 868-874.

https://doi.org/10.4236/tel.2020.104051

Received: July 7, 2020

Accepted: August 9, 2020

Published: August 12, 2020

Copyright $\odot 2020$ by author(s) and Scientific Research Publishing Inc. This work is licensed under the Creative Commons Attribution International License (CC BY 4.0).

http://creativecommons.org/licenses/by/4.0/

\begin{abstract}
The Coronavirus pandemic has clearly brought to light the profound weakness of modern societies that concerns a disappointing form of capitalism based on erroneous principles and priorities. In this short paper is discussed about both this weakness and the needed change that should put at first place: 1) the pursuit of ethical and moral principles and then those strictly economic and 2) to rethink with greater emphasis at the central role played by the State and International Organizations in the supply of public goods, including global ones. We are faced with a global crisis that must be addressed with global governance, especially in order to guarantee the supply of certain public goods, such as the health care and the safeguard of the environment which are strictly connected with each other. The Agenda 2030 and COP21 define the road map to follow.
\end{abstract}

\section{Keywords}

Coronavirus Pandemic, Capitalism, Sustainability, Global Public Goods

\section{Introduction}

The Coronavirus pandemic has brought to light a profound weakness of modern societies, in which the economy establishes the priorities of the actions to be undertaken; in other words the behaviors-that lead to economic choices-assume a primary importance. In this scenario the weakness, already discovered long time ago, concerns traditional economic theories which are applied in a complex context where a crucial role is assumed by the dynamics of interaction (Bertalanffy, 1969) ${ }^{1}$. From a sociological perspective, the functioning of modern

\footnotetext{
${ }^{1}$ According to the General System theory (Bertalanffy, 1969) the system is defined complex when the interaction dynamics imply that: a) once in the system, its entities or parts are no longer the same in the sense that they change their condition (material and non-material) and their identity, and b) the system itself becomes a new entity in transformation, because every "state" is a function of interactions dynamics. Elements of a complex system depend on specific relationships that occur within the system, for which it will not be sufficient to know the parties. These elements enjoy "constituent" characteristics, i.e. "the whole" is not the aggregation of each element.
} 
societies could be better explained by following a new and revisited theory of individual and collective action, more focused on the subjectivity and feelings that feed decisions (Bonolis et al., 2014). Furthermore, the contributions of Kahneman, Tversky, \& Slovic (1982) and Kahneman \& Tversky (2000) of cognitive psychology encouraged a new field of the economy that is cognitive economy which tries to explain the complexity of the systems. According to this branch of the economy, there is an important part of human cognition, responsible for decisions that cannot be represented by: i) the accumulation of explicit information, ii) the search of full knowledge and iii) the full rationality in the application of rules. The economic mainstream still does not accept these recent theoretical developments, then socio-economic systems continue to be explained on the basis of traditional economic principles, such as: maximizing profit, the free market and as a result the minimal role of the State, the rational behavior, the invisible hand, rational expectations and symmetrical and perfect information (Pierleoni, 2018).

In particular, the current situation shows that the principles of the free market and invisible hand-from which it follows that the optimality of an economic system depends only on individual action-have not worked properly. The optimizing behavior of individuals, aimed at pursuing private interests mainly focused on profit maximization, has revealed in conflict with the achievement of public interests. It should be noted that the growing privatization of health care has led to a downsizing of the supply of health services which are revealed insufficient during health emergency. I refer as example to the number of intensive cares and the supply of medical disposals.

Following the crisis of 2008 and 2012, most European countries adopted austerity measures focused on the reduction of public expenditure especially that in health care. Furthermore, for what concerns Italy, public health management was characterized by a growing privatization process during the years and it has been downsized in the supply of health services (Ufficio Parlamentare di Bilancio, 2019). These two factors revealed "fatal" when the life of thousands of people, with and without adequate willingness to pay, was endangered. As argued by Bruni (2011), there are economic and social goods which are crucial for the quality of life on Earth and perhaps for its survival. These goods are and will be used at the same time by many individuals, all in some cases, and therefore their supply must not be subject to laws governing the production and consumption of private goods.

Another assumption clearly "failed" is that of the condition of symmetric and perfect knowledge. Modern societies are characterized by a condition of substantial uncertainty. The uncertainty refers to the concept of imperfect knowledge that originates from information gaps or asymmetries (Knight, 1971), or in other words from the lack or loss of information. At this regard, the delay in the dissemination of information by the China Government represented a "monumental" information asymmetry. Once the information about the existence of the virus was revealed, the subsequent communications happened unclear and were late. Moreover, the coordination of information between local and central au- 
thorities did not work and some decisions were made late, such as the purchase of medical devices. The communication of the experts to the citizens has been and it is sometimes misleading and/or contradictory, also due to the fact that the virus is not yet fully known. Finally, we continue to be plagued by false news, such as claims about the effectiveness of chloroquine in the treatment of COVID-19 (Anderson et al., 2020). All these situations show also that individuals do not use information efficiently, i.e. without making systematic errors and they do not have the same ability and the same means to process it.

Another negative consequence was the lack to prevent the Pandemic. Probably with the adoption of preventive measures and the definition of adequate safety protocols-to be implemented if necessary-the impact of the virus would not have been so devastating for human life. However, these actions would have required economic resources to be devoted for a different purpose with respect that of profit maximization. At this regards it is important to note that the World Health Organization recommended to Governments to do periodic checks on the status of circulating viruses because the real threat of new epidemics would have created a global health emergency.

\section{The Crisis of the Capitalism and the Revival of the State and International Organizations}

The evolution of socio-economic systems has led to a disappointing form of capitalism based on erroneous principles and priorities. This led to a distorted attribution of value to: 1) tangible and intangible goods and services, private and public (for example foods, cars, protection of "health" and human wellbeing) and 2) remuneration of productive factors (such as profit). The protection of human life is a public good to be considered "global" (Kaul et al., 1999), and it must be guaranteed and safeguarded by modern systems, regardless of the maximization principle, rules of efficiency and austerity measures. However, the application of these principles led to a minimal role of the State and International Institutions as main providers of public goods. In other words, public interest has been subordinated to that private.

This fact has been much evident with the Pandemic that determined a deep crisis in the health system and death of many people in the World. These two events are pushing to rethink with greater emphasis at the central role played by the State and International Organizations as main providers of public goods; however this is not sufficient because it is necessary to look at new forms of institutional organization and governance able to facing transnational challenges, such as: health protection, poverty, inequalities and more generally sustainability in its broader sense ${ }^{2}$.

\footnotetext{
${ }^{2}$ The meaning of "sustainability" implies a joint and interconnected analysis of the definitions attributed to it by social and natural sciences. The concept has a multidimensional nature and each dimension aims to pursue specific objectives: 1) economic (of equity, growth and efficiency), 2) ecological (of ecosystem integrity, carrying capacity, biodiversity and resilience) and 3) social (participation, social mobility, social cohesion, cultural identity and institutional development). Moreover, the concept is characterized by a dynamism, because it changes hand in hand with the economic, social and cultural systems to which it refers (Pierleoni, 2019).
} 
Following the crises of 2008 and 2012, the international economic debate focused on a new role of the State and fiscal policy for the purpose of stimulating economic growth defined as stagnant. One part of the literature showed how fiscal stimuli, even in countries with high public debt, could produce beneficial effects on economic development. In general terms, traditional economic theories and the capitalist system, originated from them, have been strongly questioned. As example, Stiglitz in his latest book (2020), published just before the Pandemic, proposes a "progressive capitalism" that considers a renewed and fundamental role of the State. According to his vision, political reformers should re-constitute a balance between markets, State and civil society because the excessive power of the former led to: 1) a low economic growth, 2) an increase in inequalities, 3) financial instability and 4) environmental degradation. Governments should re-define markets through regulation for: 1) environment, 2) health, 3) employment and 4) more equality. Finally, the State should supply public goods for the interest of the community. Piketty in his latest book (2019) argues, in a more radical way, that for obtaining more equal society, capitalism and private property should be replaced with participatory socialism and social federalism. The first aims at to better distribution of the power within firms, and above all at the implementation of "temporary ownership" of capital; the second aims to the fight against inequalities.

Even the most influential and important stakeholders of the current capitalism, such as the world's largest group in infrastructure sector-Macquaire Wealth-and the largest investment company-Black Rock-have questioned its validity. The same opinion was expressed by representatives of the Business Roundtable, the organization made up of the CEOs of two hundred of the most important American companies, as Amazon, Apple, Ford and JP Morgan. These companies signed an agreement according to which they will undertake both new mission and activities not only focused on profits, but also on responsible behavior towards the environment, future generation and all stakeholders. This represents a clear example that the needed change of the current capitalism is not only debated in theory since there are also real signals.

The change should concern to put at first place the pursuit of ethical and moral principles and then those strictly economic. In other words, the governance of the system should observe the solidarity principle firstly and, in a broader sense, the safeguard of public and collective interests. As Mazzucato argues in an interview with The Guardian on March 18, 2020, "this is the time to bring public interests to the center of capitalism." This clearly is strictly related to a greater State involvement. This is an arduous challenge, which implies the definition of a new paradigm of social and economic development, in a scenario highly uncertain. However, it is now time to take the opportunity for change.

The road map was defined 5 years ago, with the adoption of two Acts which are the most important on a global scale: 1) the 2030 Agenda, signed by 193 countries, which includes the 17 Sustainable Development Goals (SDGs) with 169 targets and 
2) the Paris Climate Conference (COP21). These agreements-by establishing goals to be achieved and commitments to be respected-identify the path that all Countries must follow for creating sustainable society. They represent a widespread awareness that issues such as sustainable development and climate change must be treated on a global scale, based on a shared responsibility. Finally they originate from the application of an integrated and systemic approach, based on the participation of all States. Clearly the success or failure of these Agreements will depend on an effective collaboration between all the stakeholders of the society. In other words, it is necessary: 1) the real implementation of adequate measures by Governments, 2) the support of International Institutions, and 3) the active participation of the private sector, civil society and the scientific community (Seth, 2016).

This is a complex change because it involves a radical transformation at intellectual, theoretical and operational level, and the latter involves Institutions, private and civil society. Institutions (supranational, national and local) are the main actors as regards the governance of the change and they have to act as guide for an effective transition of modern societies towards sustainable systems. The implementation of adequate policies is crucial to apply the principles of new development paradigms, such as that of sustainability science (Pierleoni, 2019).

At this regard, comprehensive policy approaches have been proposed for leading the transition processes towards sustainable societies. Giovannini (2018) proposes a theoretical model that considers the Earth as a "closed system", where the Sustainable Development Goals are properly inserted. In such way the SDGs represent the basis for defining a strategy and then public policies able to: 1) improving the functioning of the system and 2) increasing the well-being of society. The integrated vision proposed with this model serves to assess whether, in the face of a shock, the system must be brought back to the conditions prior to it, where consistent with the principles of sustainable development, or whether it is appropriate to take the opportunity originated by the arising instability from the shock, to accelerate the transition to a new state of equilibrium. The second alternative is based on the concept of "transformative resilience", that is, the possibility of exploiting the instability generated by the shocks to make "leaps forward". The Pandemic represents the shock that should encourage the global community to take the opportunity to make leaps forward towards a new state of equilibrium that it can be reached only by adopting a paradigm of sustainable development, based on a new scale of priorities.

These theoretical issues have a practical significance that concerns the implementation of a radical change ranging from the economic principles of the current capitalism to the intellectual and the operational plan, that is, that of the governments, institutions and civil society called to intervene with adequate and coordinated programs and actions. This "transformative" change requires a central role of the States and International Organizations. As the coronavirus crisis suggests, the global governance is crucial in a global and hyper-connected economy, especially in order to guarantee the supply of certain public goods, 
such as the health care and the safeguard of the environment, which are strictly connected between each other. In this context, multilateral agreements, not only on a voluntary basis, are a priority and could lead to a revision of the transnational institutional structure existing today. Institutions (supranational, national and local) have to act as guide-through the implementation of adequate policies-for an effective transition of modern societies towards sustainable systems. This implies clearly also adequate skills to translate global strategies into real actions. The global strategy to follow was defined by the Agenda 2030 and the Paris Climate Conference (COP21). It is then necessary to apply effective measures; at this regards both Acts provide as a suggestion that is to put sustainable infrastructures as a driving force for the transition to sustainable systems. The global nature and the depth of the current crisis thus suggest the need but also the opportunity for policy makers to launch a vast program of global public spending, based mainly on sustainable infrastructures and on the supply of certain public goods, such as the health care and the safeguard of the environment. Clearly to realize this vast program of spending it is necessary also: i) to mobilize an huge amount of private resources and further public development aid; ii) a radical change within the institutions for what concerns planning, programming and implementation phases of investments on the basis of a new paradigm of the development of infrastructure spending.

\section{Conclusion}

The Coronavirus pandemic is an opportunity for implementing the much debated change of the capitalism system, through the re-affirmation: i) of ethical and moral principles, such as solidarity and equality, which inspired the establishment of modern societies and ii) the role of State and Supranational organizations in the provision of public goods, including global goods. Collier (2018) argues about a "moral" failure of the current capitalism which, however, can be redeemed through the introduction of new founding principles, the ethical ones.

We are faced with a global crisis that must be addressed with global governance, especially in order to guarantee the supply of certain public goods, such as the health care and the safeguard of the environment, strictly connected with each other. The Agenda 2030 with the 17 Sustainable Development Goals, and COP21 define the path to follow. Then the road to change is known, but the challenge is arduous because it concerns the acceptance of a radical transformation which embraces intellectual, scientific, and operational level. As Scheidel (2019) argues in his book on inequality, lethal pandemics, together with wars with general mobilization of the population, transformative revolutions within individual societies and the fall of States, represent events with the greatest transforming power in Human history.

\section{Statement}

The opinions expressed herein are solely those of the author and do not 
represent the view or opinion of the Presidency of Council of Ministers.

\section{Conflicts of Interest}

The author declares no conflicts of interest regarding the publication of this paper.

\section{References}

Anderson, M., Mckee, M., \& Mossialos, E. (2020). Developing a Sustainable Exit Strategy for COVID-19: Health, Economic and Public Policy Implications. Journal of the Royal Society of Medicine, 113, 176-178. https://doi.org/10.1177/0141076820925229

Bertalanffy, L. (1969). General System Theory, Foundations, Development, Applications. New York: George Braziler Inc.

Bonolis, M., Laurano, P., \& Sonzogni, B. (2014). Le "ragioni" del crimine-Devianza e razionalità soggettiva. Roma: Carocci Editore.

Bruni, L. (2011). Il significato del limite nell'economia dei beni comuni (pp. 212-225). Sophia-Ricerche sui fondamenti e la correlazione dei saperi 2011-2, III.

Collier, P. (2018). The Future of Capitalism: Facing the New Anxieties. New York: Harper Collins Publishers.

Giovannini, E. (2018). L'utopia sostenibile. Editore Laterza.

Kahneman, D., \& Tversky, A. (2000). Choices, Values, and Frames. New York: Russell Sage Foundation. https://doi.org/10.1017/CBO9780511803475

Kahneman, D., Tversky, A., \& Slovic, P. (1982). Judgment under Uncertainty. Heuristics and Biases. Cambridge: Cambridge University Press.

https://doi.org/10.1017/CBO9780511809477

Kaul, I., Grunberg, I., \& Stern, M. A. (1999). Global Public Goods: International Cooperation in the 21st Century. Oxford: Oxford University Press. https://doi.org/10.1093/0195130529.001.0001

Knight, F. (1971). Risk Uncertainty and Profit. Chicago, IL: Chicago University Press (prima ed. 1921).

Mazzucato, M. (2020). The Covid-19 Crisis: Rethinking Capitalism. The Guardian, 18 marzo 2020 .

Pierleoni, M. R. (2018). The Analysis of Inequalities: The Review of Economic Approach and Policies. Journal of Business and Economics, 9, 123-136.

Pierleoni, M. R. (2019). La sfida della sostenibilità: Il ruolo delle Istituzioni e la spesa infrastrutturale sostenibile. Rivista Verde Ambiente, 4, 5-6.

Piketty, T. (2019). Capital and Ideology. Cambridge, MA: Harvard University Press.

Scheidel, W. (2019). La grande livellatrice. Violenza e disuguaglianza dalla preistoria a oggi. Il Mulino.

Seth, N. (2016). Linking SDG Ambitions with COP21: Q\&A with Nikhil Seth. The Independent Commission on Multilateralism.

https://www.icm2016.org/linking-sdg-ambitions-with-cop21-q-a-with-nikhil-seth

Stiglitz, J. (2020). Popolo, potere e profitti. Un capitalismo progressista in un'epoca di malcontento. Einaudi.

Ufficio Parlamentare di Bilancio (2019). Lo stato della sanità in Italia. Focus tematico n. 6. http://www.upbilancio.it/wp-content/uploads/2019/12/Focus_6_2019-sanit\%C3\%A0.pdf 